\title{
Prioridade e substância na metafísica de Aristóteles
}

\author{
Lucas Angioni \\ Universidade Estadual de Campinas / Bolsista de Produtividade do CNPq \\ angioni.lucas@gmail.com
}

resumo Pretendo neste artigo analisar as noções de prioridade reconhecidas por Aristóteles e examinar quais são os tipos de prioridade pelos quais ele demarca a primazia da substância em sua metafísica. Tentarei mostrar que a interpretação tradicional, que entende a prioridade ontológica da substância em termos de "existência independente", não pode ser aceita. Em vez de prioridade em termos de existência, Aristóteles atribui à substância uma prioridade em termos de completude, bem como propõe certo tipo de prioridade causalexplanatória como característica das substâncias de algo. Além disso, Aristóteles argumenta, contra o platonismo, que esses dois tipos de prioridade (a prioridade em termos de completude e a prioridade causal-explanatória) não podem ser confundidos.

palavras-chave Ontologia; Substância; Essencialismo; Prioridade; Causalidade; Definição

I.

Meu objetivo neste artigo consiste em analisar as relações entre a noção de substância e as noções de prioridade na metafísica de Aristóteles. No livro VII de sua Metafísica (1028a 30-32), Aristóteles afirma que a substância é primeira entre os entes de acordo com três critérios: por definição, pelo conhecimento e pelo tempo. Dado que parece não haver dificuldade em inferir que a substância, sendo primeira, é anterior a todos os demais entes, pode-se dizer que a substância detém três tipos de prioridade sobre os demais entes: por definição, pelo conhecimento e pelo tempo.

Recebido em 02 de setembro de 2009. Aceito em 12 de dezembro de 2009.

doispontos, Curitiba, São Carlos, vol. 7, n. 3 - especial, p.75-106, abril, 2010 
No entanto, não é muito claro o que querem dizer essas afirmações de Aristóteles no início de Metafísica VII, e, ainda que fossem claras, elas se apresentam como algo preliminar no itinerário argumentativo que ocupará Aristóteles em seguida. Dizer que elas são preliminares não quer dizer que elas são falsas ou que Aristóteles as rejeitará ao final de sua investigação: dizer que elas são preliminares quer dizer que elas estão longe de esgotar o assunto, quando se trata de saber quais são as relações entre a noção de substância e as várias noções de prioridade. $\mathrm{O}$ assunto se complica razoavelmente porque Aristóteles às vezes recorre a certa noção de prioridade pelo ser (toi einai) ${ }^{1}$ como característica da substância, e não é claro se essa noção de prioridade pode ser reduzida a uma das três reconhecidas em 1028a 32-33. Tampouco é claro se essa noção de prioridade pelo ser é característica própria da substância ou não. Além do mais, em vários passos da Metafísica Aristóteles utiliza o termo "substância" no dativo (ousiai), ou a expressão "segundo a substância" (kata ten ousian), para se referir a outro tipo de prioridade. Mas não é claro se tudo que satisfaz essa noção de "prioridade em substância" pode ser considerado uma substância. ${ }^{2}$

Assim, meu propósito consiste em formular essas dificuldades de modo claro e discutir uma possível interpretação sobre o modo pelo qual a substância possui prioridade sobre os demais seres. Nessa perspectiva, examinarei brevemente os tipos mais relevantes de prioridade que Aristóteles parece reconhecer ${ }^{3}$. Em seguida, tentarei delimitar quais são os tipos relevantes de prioridade para caracterizar a ousia na metafísica de Aristóteles.

\section{II.}

Aristóteles reconhece vários tipos de prioridade, e não pretendo fazer um estudo exaustivo deles. Pretendo apenas selecionar aqueles tipos que parecem ser os mais decisivos para caracterizar a substância.

Assim, começo pela constatação dos tipos de prioridade relevantes para nosso propósito. Temos, inicialmente, a prioridade lógica, a prioridade definitória e a prioridade pelo conhecimento. ${ }^{4}$ Este último tipo parece envolver dois casos bem distintos: ou bem se trata de uma priori- 
dade no conhecimento "para nós", na ordem da descoberta, ou na ordem em que nos é mais fácil elucidar certas noções e adquirir certas informações; ou bem se trata de uma prioridade no conhecimento "por natureza" e, neste caso, tal prioridade parece ser equivalente à prioridade definitória, ou equivalente à prioridade causal-explanatória (que introduziremos mais adiante). Por outro lado, há ainda outros tipos de prioridade, os quais seriam mais bem classificados como tipos de prioridade ontológica. Nesse terreno, pode-se falar em prioridade em termos de condições de existência, bem como em prioridade em termos de “excelência pelo ser" (Metafísica 1077b 3).

Antes de prosseguir e fornecer descrição mais satisfatória de cada um desses tipos de prioridade, devo sublinhar algo que parece ser comum a todos eles. Toda relação de prioridade envolve dois pólos, opostos entre si de modo complementar e assimétrico. Não faz sentido dizer que " $x$ é anterior", a não ser que se especifique um correlato ao qual ele é anterior: se $x$ é anterior, é porque existe um $y$ ao qual ele é anterior, de modo que a expressão completa para descrever o predicado "anterior" consiste em " $x$ é anterior a $y$ ". Além disso, ou por isso mesmo, se é verdade dizer que $x$ é anterior a $y$, é também verdade dizer que $y$ é posterior a $x$ : “anterior" e "posterior" são designações correlativas que se complementam. Por outro lado, se é verdade dizer que $x$ é anterior a $y, x$ deve ter algumas características relevantes que $y$ não tem, pelas quais se demarca a assimetria na comparação entre ambos.

Estabelecidos esses pontos mínimos, tentarei caracterizar os cinco ou seis tipos de assimetria até aqui mencionados. Começo pela relação de prioridade lógica. Esse tipo de prioridade define-se pela assimetria nas relações de implicação entre dois itens, sejam eles termos ou proposições. Dado que "implicação" é um termo bem vago e confuso, cumpre-me dizer que, neste contexto, utilizo "implicação" (ou "acompanhamento", ou "conseqüência”) para me referir àquilo que Aristóteles, em grego, designou como "akolouthêsis tou einai" (Categorias 14a 30). De fato, o termo "akolouthêsis", no vocabulário aristotélico, designa, entre outras coisas, a relação de acarretamento entre duas proposições, tal como hoje dizemos "se $p$, então q". Mas esse sentido proposicional de "implicação" não será relevante para nossos propósitos. A rigor, no entanto, Aristóteles fala em "akolouthêsis tou einai" para se referir, antes, a relações de acom- 


\section{8}

panhamento ou implicação entre termos. Um termo "acompanha"ou "implica" outro se ele não pode ser o caso sem que o outro seja o caso, ou seja, se o outro se lhe segue 5 . Pode parece estranho dizer que "um termo é o caso", mas, quando Aristóteles emprega expressões como essa, ele está a tomar os termos como predicados que, atribuídos a um dado sujeito que os instancia, são o caso. Assim, de acordo com a implicação do ser o caso ("akolouthêsis tou einai"), podemos comparar as relações de prioridade entre os termos "animal" e "mortal". Para tanto, devemos referir os dois termos a um mesmo sujeito (um terceiro termo $x$ ) e averiguar quais são os "acompanhamentos"ou implicações entre as duas predicações que assim se formam, "x é $A$ " e " $x$ é $B$ ". Pelo nosso exemplo, deve-se averiguar se a verdade da predicação " $x$ é animal" implica (no sentido de não poder ser separada de) a verdade da predicação " $x$ é mortal", bem como, inversamente, deve-se averiguar se a verdade da predicação " $x$ é mortal" implica a verdade da predicação " $x$ é animal". Ora, é claro que a verdade da predicação " $x$ é animal" implica a verdade da predicação " $x$ é mortal”, pois não pode existir $x$ que, sendo animal, não seja mortal. 6 No entanto, a verdade da predicação " $x$ é mortal” não implica a verdade da predicação " $x$ é animal", porque " $x$ é mortal" pode ser verdadeira independentemente da verdade de " $x$ é animal" (isso ocorre, obviamente, quando $x$ é uma planta). O resultado dessa comparação é que "mortal" é anterior a "animal". É a esse tipo de prioridade que me refiro neste artigo, quando uso a expressão "prioridade lógica". Qualifico de "lógica" tal tipo de prioridade em atenção ao fato de que ele é determinado de acordo com relações de implicação entre as condições sob as quais dois predicados podem ser verdadeiramente atribuídos a um mesmo sujeito. ${ }^{7}$

Há três pontos que agora cumpre elucidar. Primeiro, por que essa relação de prioridade não é concebida do modo inverso ("animal" como anterior a "mortal”). Segundo, qual é o vocabulário de Aristóteles para exprimir esse tipo de prioridade. Terceiro, por que esse tipo de prioridade lógica não pode ser reduzido à prioridade em termos de definição, da qual tratarei em seguida.

Quanto ao primeiro ponto, alguém poderia perguntar: por que Aristóteles não diz, antes, que animal é anterior a mortal? Ora, se sei que $x$ é animal, posso inferir com segurança que $x$ é mortal, mas não o inver- 
so. De fato, se sei que $x$ é mortal, não posso inferir que $x$ é animal. Resulta disso que o termo "animal", como ponto de partida para inferências, é mais poderoso do que o termo "mortal". ${ }^{8} \mathrm{E}$, por ser mais poderoso como ponto de partida para inferências, "animal" poderia plausivelmente receber o título de "anterior a mortal".

A resposta a esse problema é simples. Aristóteles reconhece o aspecto em que se deve dizer que "animal" é anterior a "mortal", mas esse aspecto não se configura como prioridade lógica. De fato, "animal” pode ser concebido como anterior a "mortal" de acordo com vários outros tipos de prioridade: de acordo com certa prioridade no conhecimento, medida pela capacidade que um termo tem de servir como ponto de partida para o conhecimento de outros; de acordo com certa prioridade explanatória, medida pela capacidade que um termo tem de servir como ponto de partida para a explicação de outros; bem como de acordo com a prioridade que Aristóteles relata sob o título de "prioridade de acordo com a ordem", em Categorias 14a 35-b 3, a qual parece envolver certo amálgama das duas anteriores. No entanto, nenhum desses outros tipos de prioridade deve ser caracterizado como "lógico", no sentido que propus. A prioridade lógica é, assim, concebida em termos de assimetria nas relações de implicação, de tal modo que o item reconhecido como "anterior" é tal que satisfaz conjuntamente as duas condições seguintes:

(i1) o item anterior é logicamente independente do item que lhe é posterior (no sentido de que as condições que tornam verdadeira a atribuição do termo "mortal" a um dado sujeito não dependem das condições que tornariam verdadeiro atribuir "animal" a esse mesmo sujeito);

(ii1) a verdade de sua atribuição a um dado sujeito é condição sine qua non para atribuir verdadeiramente a esse mesmo sujeito o item que lhe é posterior (" $x$ é animal” não pode ser verdadeira, a não ser que " $x$ é mortal” seja também verdadeira).

Isso nos leva ao problema do vocabulário. Aristóteles por vezes parece utilizar expressões como "logoi" (logos no dativo) ou "kata ton logon" ("de acordo com o logos") para introduzir esse tipo de prioridade. ${ }^{9}$ No entanto, essas mesmas expressões introduzem, em vários contextos, o tipo de prioridade que chamo de "definicional" ou "definitória", do qual me ocuparei logo mais, e que não pode ser reduzido à prioridade lógica (ainda que possa ser concebido de tal modo que envolva a prioridade lógica). Para se 
referir à prioridade lógica, Aristóteles emprega outras expressões, relacionadas à assimetria nas relações de acompanhamento recíproco na aplicação de dois predicados. Assim, em Categorias 14a 30, é chamado de "anterior" o item que "não admite a conversão recíproca quanto ao acompanhamento (ou implicação) do ser o caso", e essa expressão do jargão aristotélico deve ser compreendida pela conjunção de duas condições complementares entre si: por um lado, o item anterior, quando é verdadeiramente atribuído a um dado sujeito $x$, não é acompanhado pelo item que lhe é posterior (ou seja: " $x$ é mortal" pode ser verdadeira sem que " $x$ é animal" seja também verdadeira); por outro lado, o item que é posterior não pode ser atribuído verdadeiramente ao mesmo sujeito $x$ a não ser que lhe acompanhe a atribuição verdadeira do item anterior (ou seja: " $x$ é animal" não pode ser verdadeira, a não ser que " $x$ é mortal" seja também verdadeira). De modo similar, essa noção de prioridade lógica é muitas vezes introduzida pela expressão “ $A$ pode ser sem $B$ ”, na qual "poder ser sem" quer dizer apenas "que a predicação de $A$ pode ser verdadeira sem que a predicação de $B$ seja verdadeira, em relação a um mesmo sujeito $x " .{ }^{10}$ Para desespero dos leitores, no entanto, essas expressões, " $A$ pode ser sem $B$ ” e "o que não admite a conversão recíproca quanto à implicação do ser o caso", tampouco são usadas exclusivamente para introduzir a prioridade lógica, pois elas podem referir-se também à prioridade concebida como independência quanto a condições de existência. ${ }^{11}$

Isso nos leva ao terceiro ponto. Poder-se-ia julgar que a prioridade que estou descrevendo como "lógica" poderia ser reduzida à prioridade definicional. A resposta, no entanto, é cabalmente negativa. ${ }^{12}$ Alguém poderia insistir na presumida identificação entre a prioridade lógica e a definicional do seguinte modo. Tome-se a comparação entre "animal" e "mortal". Alguém poderia dizer que "mortal", embora seja anterior a "animal" do ponto de vista lógico, não seria anterior a "animal" do ponto de vista definicional, porque o enunciado definiens de "animal" não precisa mencionar o termo "mortal". De fato, pode-se dizer que "animal" está bem definido pelo enunciado "ser vivo dotado de capacidade de percepção". No entanto, alguém poderia sabiamente observar que o termo "mortal" parece estar incluído na definição de "ser vivo". Embora isso seja discutível, concedamos esse ponto, em vista do argumento. Assim, se poderia concluir que "mortal", ainda que não seja imediata- 
mente mencionado no enunciado definiens de "animal", poderia ser obtido desse enunciado por mera definição dos termos nele incluídos, de modo que se poderia dizer que "mortal" está mediatamente incluído no enunciado definiens de "animal". Com esse resultado, se poderia argumentar que a presumida distinção entre prioridade lógica e prioridade definicional colapsa totalmente.

No entanto, para que esse argumento constituísse objeção real à distinção que proponho, ter-se-ia que provar que isso é assim em todos os casos. Ou seja: ter-se-ia que provar que todos os predicados necessários de um dado sujeito $S$ seriam, mediata ou imediatamente, suscetíveis de serem incluídos no enunciado definiens de $S$. No entanto, embora muitos dos predicados incluídos no enunciado definiens de um dado $S$ satisfaçam a noção de prioridade lógica em relação ao definiendum, daí não se segue que todos os predicados que satisfazem a noção de prioridade lógica em relação a um dado $S$ devam ser incluídos no enunciado definiens de $S$. Basta provar isso com um exemplo.

É verdade dizer que "todas as bigornas são pesadas", pois é impossível encontrar um $x$ do qual seja verdadeiro dizer " $x$ é bigorna" e não seja verdadeiro dizer " $x$ é pesado". Mas, dado que é possível encontrar um $x$ do qual seja verdadeiro dizer " $x$ é pesado" sem que seja verdadeiro dizer " $x$ é bigorna", pode-se concluir que "pesado" é anterior a "bigorna" de acordo com a prioridade lógica. No entanto, seria difícil sustentar que a propriedade de ser algo pesado deveria ser incluída na definição da bigorna. Ainda que Aristóteles não tenha pensado em bigornas, é claro que ele concebeu que todos os artefatos, bem como todos os entes naturais, devem ser definidos por suas respectivas funções próprias (talvez acompanhadas por certas propriedades estritamente necessárias para o desempenho das funções)..$^{13}$ Se o exemplo da bigorna não satisfaz o leitor, basta substituí-lo pelo exemplo do serrote, que encontramos em Física 200a 5-8.

Já disse algo sobre a noção de prioridade definicional, para distinguila da noção de prioridade lógica. Passo, agora, a falar dela em si mesma. A prioridade definicional consiste na relação assimétrica em que, de dois itens dados, $A$ e $B, A$ é anterior a $B$ pelo fato de $A$ estar contido no enunciado definiens de $B$, mas não conversamente. Ou seja, deve-se dizer que $A$ é anterior a $B$, do ponto de vista da prioridade definicional, se as duas seguintes condições são conjuntamente satisfeitas: 
$\left(i_{2}\right)$ A pode ser definido independentemente de $B$, por um enunciado definiens em que o termo $B$ não é mencionado nem está implicitamente contido;

(ii 2 ) $B$ não pode ser definido independentemente de $A$, ao contrário, o enunciado definitório de $B$ inclui $A$ como um de seus termos (ou inclui implicitamente o termo $A$ como algo que poderia ser obtido por análise de um dos termos explicitamente contidos no enunciado).

À primeira vista, como já foi discutido, poderia parecer que a prioridade definicional pudesse ser reduzida à prioridade lógica. De fato, a prioridade lógica estabelece que " $A$ é anterior a $B$ " no sentido de que " $B$ não pode ser o caso sem $A$ ": a verdade de " $x$ é $A$ " se segue necessariamente da verdade de " $x$ é $B$ ”. Daí se poderia inferir que, se a verdade de " $x$ é $A$ " se segue necessariamente da verdade de " $x$ é $B$ ", então " $B$ " deveria ser definido através de " $A$ ", no sentido de que " $A$ " seria um termo contido no enunciado definiens de " $B$ ". No entanto, Aristóteles não concebe essa inferência como legítima. Não há nem sequer co-extensão entre o que é anterior pela prioridade lógica e o que é anterior pela prioridade definicional. ${ }^{14}$

Por um lado, não é verdade que todo item que é anterior pela prioridade lógica seja anterior também pela prioridade definicional, como já mostramos acima. Por outro, tampouco é verdade que todo item que é anterior pela prioridade definicional seja anterior também pela prioridade lógica. Suponha-se, por exemplo, que o ser humano seja definido pela atividade racional da alma: "ser humano é (df.) o animal dotado de atividade racional da alma”. Se a prioridade lógica acompanhasse todos os casos de prioridade definicional, seria preciso que a verdade de " $x$ é dotado de atividade racional da alma" sempre acompanhasse a verdade de " $x$ é um ser humano". Mas esse acompanhamento não se verifica, quando $x$ é um bebê. Poder-se-ia argumentar que esse presumido contra-exemplo não oferece objeção séria à pretensão que ele quer combater, pois a falsidade de "um bebê é dotado de atividade racional da alma" poderia ser corrigida pela adição da cláusula "em potência”, engendrando a seguinte sentença verdadeira: "um bebê é, em potência, dotado de atividade racional da alma". ${ }^{15}$ Poder-se-ia acrescentar que a definição de tipos naturais, como o ser humano, deve ser feita em atenção à plena efetividade dos indivíduos adultos e não precisaria 
contemplar as contingências do processo de reprodução dos indivíduos do mesmo tipo específico.

Essa objeção é bem aceitável e, por essa razão, tomo outro exemplo, discutido na literatura recente sobre o essencialismo de Aristóteles ${ }^{16}$. Suponha-se, por exemplo, que o elemento fogo seja definido pela propriedade de repousar em seu lugar natural, que é o alto, ou a posição extrema na esfera sublunar: "fogo é (df.) o elemento que repousa no alto como em seu lugar natural". Se a prioridade lógica acompanhasse todos os casos de prioridade definicional, seria preciso que a verdade de " $x$ repousa no alto como em seu lugar natural" sempre se seguisse da verdade de " $x$ é fogo". No entanto, essa conseqüência não se verifica em parte significativa dos casos: há quantidade bem considerável do elemento fogo que não está a repousar, em dado momento, no alto, isto é, na posição mais exterior da esfera sublunar ${ }^{17}$.

A prioridade definicional está intimamente ligada à prioridade causalexplanatória, que discutiremos depois. A título de antecipação, podemos dizer que satisfazer a prioridade lógica não é, estritamente, uma condição necessária para que algo satisfaça a noção de prioridade definicional. $\mathrm{O}$ que caracteriza a prioridade definicional é, antes, a relevância explanatória ou causal. Se $A$ satisfaz em relação a $B$ os dois critérios $\left(i_{2}\right)$ e (ii 2 ) há pouco mencionados, $A$ tem em relação a $B$ uma prioridade pela qual se diz que $A$ desempenha papel causal relevante para explicar por que $B$ é o que é (ou por que $B$ tem as propriedades que o fazem ser o que ele é). Mas esse papel causal nem sempre é acompanhado pela satisfação dos critérios que dariam a $A$ prioridade lógica sobre $B$, nos termos em que "prioridade lógica" foi há pouco definida.

Passemos a outro tipo de prioridade, a prioridade pelo conhecimento. Esse tipo de prioridade deve ser subdividido em duas espécies. Por um lado, se "conhecer" é entendido no sentido trivial de adquirir informações, ou tomar notícia, etc., há uma prioridade na ordem do conhecimento "para nós". Por outro lado, se "conhecer" é entendido no sentido forte de conhecimento científico (que satisfaz os critérios expostos por Aristóteles no livro I dos Segundos Analíticos), há uma prioridade na ordem do conhecimento "por natureza"18. No sentido ordinário de "conhecimento", deve-se dizer que $A$ é anterior a $B$ se os seguintes critérios forem satisfeitos conjuntamente: 


\section{4}

$\left(i_{3}\right)$ o conhecimento de $A$ pode ser adquirido por nós sem conhecer $B$;

$\left(i i_{3}\right)$ mas o conhecimento de $B$ não pode ser adquirido por nós sem o conhecimento de $A$.

Esse primeiro tipo de prioridade pelo conhecimento pode ser ilustrado pelo tipo de prioridade que as informações sensíveis a respeito de objetos singulares detêm sobre uma noção universal obtida por indução ou generalização. ${ }^{19} \mathrm{Em}$ geral, essa prioridade corresponde à ordem da "descoberta". Assim, podemos tomar notícia de que este cavalo é herbívoro sem saber que todo cavalo é herbívoro, o que satisfaz a primeira condição acima estipulada. Mas, se sabemos que todo cavalo é herbívoro, não podemos não saber que este cavalo é herbívoro, ${ }^{20}$ o que satisfaz a segunda condição.

No sentido estrito de "conhecimento", deve-se dizer que $A$ é anterior a $B$ se os seguintes critérios forem satisfeitos conjuntamente:

$\left(i_{4}\right)$ a explicação adequada de por que $A$ é o caso não requer a explicação adequada de por que $B$ é o caso;

$\left(\mathrm{ii}_{4}\right)$ mas a explicação adequada de por que $B$ é o caso requer o princípio de que $A$ é o caso $^{21}$.

Em vez de " $A$ ser o caso", poderíamos formular os critérios com a expressão " $A$ ser aquilo que $A$ é". ${ }^{22}$ Teríamos, assim, o seguinte: $\left(i_{4}\right)$ a explicação adequada de por que $A$ é o que é não requer a explicação adequada de por que $B$ é aquilo que $B$ é; $\left(i i_{4}\right)$ mas a explicação adequada de por que $B$ é aquilo que é (ou tem as propriedades que fazem dele aquilo que ele é) requer o princípio de que $A$ é aquilo que $A$ é.

Esse tipo de prioridade pelo conhecimento em muitos casos corresponde à prioridade definicional, dado que a definição da essência é princípio para o conhecimento científico. Mas, de modo geral, pode-se dizer que esse segundo tipo de prioridade pelo conhecimento corresponde à prioridade causal-explanatória, da qual nos ocuparemos mais adiante ${ }^{23}$.

\section{III.}

Passemos, então, aos tipos de prioridade que poderiam ser caracterizados como "ontológicos". Em primeiro lugar, temos a prioridade concebida como independência quanto às condições de existência. Neste caso, $A$ é 
anterior a $B$ se os seguintes requisitos forem conjuntamente satisfeitos:

$\left(i_{5}\right)$ A pode existir independentemente de $B$, ou seja, pode existir sem que $B$ exista ao mesmo tempo;

(ii 5 ) $B$ não pode existir independentemente de $A$, ao contrário, se $B$ existe, $A$ necessariamente existe ao mesmo tempo. ${ }^{24}$

Poderia parecer que esse tipo de prioridade se confunde com a prioridade lógica tal como antes definida. De fato, a prioridade lógica envolve dois termos que, referidos a um sujeito comum, $x$, tornam-se predicados cujas condições de verdade são comparadas entre si. Os dois termos (como "animal" e "mortal" no exemplo que usei) introduzem propriedades cuja existência pode ser reduzida ao fato de ser instanciada em um dado sujeito. Isso quer dizer que a verdade da predicação " $x$ é animal" pode ser entendida como equacionável à verdade da sentença “(um) animal existe" (isto é, existe um $x$ que é animal)25. É plausível que alguém se sinta autorizado a reduzir ambos esses tipos de prioridade a um só, pois, sob certas condições, eles parecem fornecer os mesmos resultados: dado que "mortal" é anterior a "animal" conforme à prioridade lógica, segue-se que a propriedade de ser mortal pode existir independentemente da existência da propriedade de ser animal, etc. No entanto, a prioridade como independência quanto a condições de existência é claramente distinta da prioridade lógica, pelas seguintes razões.

Primeiro, a prioridade como independência quanto a condições de existência (ou, para simplificar a expressão, a prioridade em existência) pode ser perfeitamente concebida sem referência a um sujeito comum, $x$, ao qual seriam atribuídos ambos os itens a serem comparados. Podemos comparar o Sol com os animais e dizer qual deles tem prioridade, entendida como independência quanto à existência. De fato, se não existissem animais, o Sol poderia continuar a existir, pois sua existência não depende da existência de animais. No entanto, se o Sol não existisse, os animais não poderiam existir, pois sua existência depende de algum modo da existência do Sol. ${ }^{26}$ Podemos estabelecer, portanto, a prioridade do Sol sobre os animais sem recorrer a um sujeito comum $x$, ao qual seriam atribuídos os predicados "Sol" e "animal". As relações entre as condições de existência do Sol e dos animais não dependem de os termos "Sol" e "animal" serem atribuíveis a um mesmo $x$. 
Por outro lado, diversos casos de prioridade lógica não envolvem nenhum compromisso ontológico com a noção de "anterior em existência independente". Suponha-se os termos "quadrúpede alado" e "dragão".27 Ora, "quadrúpede alado" é anterior a "dragão", pois, se é verdade que " $x$ é dragão", segue-se que é verdade que " $x$ é quadrúpede alado", embora não conversamente, dado que a verdade de " $x$ é quadrúpede alado" é compatível com a falsidade de " $x$ é dragão" (no caso de Pégaso, por exemplo). Podemos falar em prioridade lógica entre esses termos. No entanto, nenhum desses termos denota coisas existentes, nem "quadrúpede alado", nem "dragão", nem "Pégaso", de modo que seria falso dizer que quadrúpede alado é anterior em existência a dragão. Isso basta para provar que a prioridade lógica não pode ser confundida com a prioridade em existência. A prioridade lógica apenas estabelece que, se existissem os termos $A$ e $B$, então $A$ seria anterior a $B .^{28}$

\section{IV.}

Falta-me ainda introduzir dois outros tipos relevantes de prioridade. No entanto, será mais elucidativo introduzi-los depois de considerar certos problemas que motivam este artigo. Como já disse na seção inicial deste artigo, Aristóteles atribui à noção de substância (ousia) a característica de ser "anterior" em vários sentidos: (i) pela definição (logôi), (ii) pelo conhecimento (gnosei) e (iii) no tempo (chronôi). ${ }^{29}$ Nossos problemas podem ser divididos em duas ordens: primeiro, trata-se de saber o que cada uma dessas três prioridades significam - tarefa a que já nos dedicamos, nas seções anteriores. Segundo, trata-se de saber se esses três tipos de prioridade são, de fato, suficientes para caracterizar a prioridade pela qual a ousia ocupa posição privilegiada na metafísica de Aristóteles.

Quanto ao primeiro ponto, a primeira resposta parece ser fácil. A prioridade logôi introduzida por Aristóteles em 1028a 32 e explicada em 1028a 34-36 parece ser exatamente a prioridade que antes classificamos como prioridade definicional, aplicada às noções de "substância" e "demais categorias". Se é assim, os requisitos que definem esse tipo de prioridade têm de ser satisfeitos: $\left(i_{2}\right)$ a substância deve poder ser definida independentemente das demais categorias, por um enunciado definiens em que nenhu- 
ma outra categoria é mencionada nem está implicitamente contida; $\left(\mathrm{ii}_{2}\right)$ as demais categorias não podem ser definidas independentemente da substância, ao contrário, o enunciado definitório de cada categoria deve incluir necessariamente a noção de substância ${ }^{30}$. No entanto, pode-se perguntar se a condição $\left(i_{2}\right)$ é realmente satisfeita. Poderia a substância ser definida sem mencionar as demais categorias? Ao menos há razões para julgar que uma substância não poderia ser definida sem menção a propriedades contidas em outras categorias. Voltarei a esse ponto.

Por outro lado, quanto à prioridade pelo conhecimento, Aristóteles passa da menção ao uso dos termos "substância" e "demais categorias", em 1028a 36- b2. Não mais se trata de saber quais são as relações de prioridade entre as noções de "substância" e "demais categorias". Trata-se de saber se, dado um objeto qualquer, conhecemo-lo mais por conhecer sua substância ou por conhecer alguma sua propriedade que se classifica em outra categoria. Por exemplo, dado o fogo, conhecemo-lo mais por conhecer sua substância (ou essência) ou por conhecer que ele tem tal e tal propriedade qualitativa? O tipo de prioridade que está em questão, neste caso, parece ser a prioridade na ordem do conhecimento por natureza: $\left(i_{4}\right)$ a explicação adequada de por que o fogo tem tal essência não requer a explicação adequada de por que o fogo tem tal e tal qualidade; $\left(\mathrm{ii}_{4}\right)$ mas a explicação adequada de por que o fogo tem tal e tal qualidade requer o princípio de que o fogo tem tal essência.

As coisas tornam-se bem mais difíceis em relação à prioridade da substância no tempo. Suponhamos, de acordo com a orientação interpretativa mais aceita, ${ }^{31}$ que a característica de ser a única categoria a que se aplica a noção de "separado" seja a explicação dada por Aristóteles para a prioridade da substância "no tempo", em 1028a 33-34. Em 1050a 3, Aristóteles aproxima a prioridade no tempo (kata chronon) à prioridade na geração ou no devir (kata genesin) e, se estiver correto o equacionamento entre esses dois tipos de prioridade, podemos dizer que Aristóteles concebe a prioridade da substância no tempo em termos de condições de possibilidade do devir e condições de possibilidade de uma descrição coerente do devir. De fato, Aristóteles parece ter em mente a satisfação conjunta dos seguintes requisitos:

$\left(i_{6}\right)$ um processo de devir em que $x$ sofre mudança não-substancial (isto é, uma alteração, ou um crescimento, ou um deslocamento) não 


\section{8}

pode ser concebido a não ser que $x$ já esteja pressuposto como uma substância;

(ii 6 ) mas um processo de devir em que $x$ é gerado substancialmente não exige que $x$ já esteja pressuposto com alguma propriedade que lhe é acidental.

Ora, esses dois requisitos são plenamente satisfeitos na teoria do devir exposta em Física I, na qual a substância é introduzida como subjacente que está pressuposto em todas as mudanças não-substanciais. ${ }^{22}$ Talvez não por acaso, nesse mesmo contexto de discussão (cf. 188a 6), Aristóteles pressupõe que a substância é a única categoria do ser que merece ser designada sob a noção de "separado", a mesma que ocorre em 1028a 34 para justificar a tese de que a substância é anterior no tempo.

A questão que se impõe, neste contexto, é a seguinte: essa prioridade no tempo, sob a qual a substância recebe o título de "algo separado", pode ser equacionada à prioridade como independência quanto a condições de existência? E, se a resposta for positiva, poderíamos dizer que a prioridade em existência seria suficiente para caracterizar a primazia ontológica da substância sobre os demais entes?33 Esta última questão consiste em uma das motivações básicas deste artigo.

Comecemos por esta última questão. Se a prioridade em existência fosse suficiente para determinar a primazia ontológica da substância, seria impossível encontrar algo que, não sendo substância, mesmo assim satisfizesse os requisitos para ser considerado como "anterior em existência". No entanto, é possível encontrar casos em que, de dois itens, aquele que não é substância é "anterior em existência" ao outro, que é uma substância. De fato, o calor é anterior em existência ao animal, pois $\left(i_{5}\right)$ o calor pode existir independentemente da existência de animais; $\left(\mathrm{ii}_{5}\right)$ mas nenhum animal pode existir independentemente da existência do calor, ao contrário, se há animais, necessariamente existe calor ao mesmo tempo. No entanto, o calor não é uma substância, sendo, porém, anterior a um amplo gênero de substâncias (os animais) quanto às condições de existência. Isso prova, assim, que a prioridade em existência não é suficiente para determinar a primazia ontológica da substância.

Por outro lado, devemos perguntar se a prioridade em existência seria de fato uma condição necessária para a primazia ontológica da substân- 
cia. Toda substância, na medida em que é uma substância, deveria satisfazer conjuntamente os critérios $\left(\mathrm{i}_{5}\right)$ e $\left(\mathrm{ii}_{5}\right)$ ?

Esse ponto não é muito claro no texto de Aristóteles e não tem sido suficientemente discutido na literatura secundária. ${ }^{35}$ Suponha-se que a prioridade em existência em relação às demais categorias seja condição necessária para estabelecer a primazia ontológica da substância sobre as demais categorias. Nesse quadro, os seguintes requisitos deveriam ser conjuntamente satisfeitos: $\left(i_{5}\right)$ a substância deveria poder existir independentemente de qualquer propriedade contida nas demais categorias, ou seja, poder existir sem que uma tal propriedade exista ao mesmo tempo; $\left(\mathrm{ii}_{5}\right)$ uma propriedade qualquer classificada sob outra categoria não poderia existir independentemente de uma substância. Pois bem: ainda que o requisito $\left(\mathrm{ii}_{5}\right)$ seja satisfeito, ${ }^{36}$ é difícil ver como poderia ser igualmente satisfeito o requisito $\left(i_{5}\right) \cdot 37$ Não se trata do requisito mais fraco de que a substância deveria poder existir independentemente de qualquer propriedade que, contida nas demais categorias, lhe fosse acidental. Mesmo um tal requisito, no entanto, seria satisfeito apenas pelas substâncias incorruptíveis, isto é, os corpos celestes e o Primeiro Motor. Trata-se do requisito mais geral de que uma substância deveria poder existir independentemente de qualquer propriedade classificada sob as outras categorias.

Isso nos leva, finalmente, à outra questão que há pouco formulamos. A prioridade no tempo, sob a qual a substância recebe o título de "algo separado", poderia ser equacionada à prioridade como independência quanto a condições de existência? Ora, parece que a resposta deve ser negativa, visto que a prioridade em existência não pode ser concebida nem como condição necessária nem como condição suficiente para algo ser substância, ao passo que Aristóteles jamais hesita em atribuir à substância o título de "separado", o qual, de fato, é co-extensivo com a noção de "substância". 38

O que, no entanto, Aristóteles quer dizer com o título "separado"? Se esse título não corresponde à prioridade em termos de condições de existência, o que ele designa?39 Chegamos ao ponto em que se torna propício introduzir outra noção de prioridade, a qual é assinalada, em Metafísica 1077b 2, pela expressão "em substância" (ousia no dativo). O texto de Aristóteles diz o seguinte: "são anteriores em substância as coisas que, separadas [chorizomena], são excelentes pelo ser [tôi einai hyper- 
ballei]" (1077b 2-3). Do ponto de vista sintático, "tôi einai” está com o verbo principal "hyperballei" 40 . O sentido dessa expressão será discutido logo mais. Começo por ressaltar que "tôi einai" não forma com o particípio "chorizomena" uma expressão única, que introduzisse a noção de separabilidade em existência. De fato, poder-se-ia argumentar que "chorizomena tôi einai" introduz, como requisito para algo ser considerado como "anterior em substância", a separabilidade em existência, concebida como conjunção dos seguintes critérios: $\left(i_{5^{\prime}}\right)$ A pode existir separadamente de $B$, ou seja, pode existir sem que $B$ exista ao mesmo tempo; (ii $5_{5}$ ) $B$ não pode existir separadamente de $A$, ao contrário, se $B$ existe, $A$ necessariamente existe ao mesmo tempo. No entanto, o texto de Metafísica XIII não opera com tal noção de separabilidade em existência. O requisito para algo ser considerado como "anterior em substância" está relacionado à noção de todo perfeito e acabado (teleion), a qual, um pouco antes no argumento do livro XIII da Metafísica, em 1077a 31-32, foi utilizada como condição suficiente para considerar corpos como substâncias (em contraste com as entidades matemáticas, às quais os platônicos outorgaram o título de substâncias).

Tentarei ser breve e claro. A noção tradicional de "separação" está tão contaminada com a noção de "independência existencial", que se torna dificil compreendê-la de outro modo. No entanto, julgamos que, nos contextos em que "choriston" é introduzido como marca própria da primazia ontológica das substâncias na mobília do mundo, o termo tem outro significado. Nesses contextos, "choriston" quer dizer que uma substância consiste em um todo autônomo, ao qual nada falta para que ele seja o que ele é. Esta última expressão, "ao qual nada falta para que ele seja o que ele é", constitui uma paráfrase da definição de "acabado" ou "perfeito" ("teleion”) em Metafísica 1021b 12-13. Tanto a definição como também a paráfrase são vagas. Podemos dizer, diante de uma flauta que nos parece excelentemente construída e adaptada para sua função, que "essa flauta é perfeita", e a ela nada falta para ser uma flauta. No entanto, em outro sentido, é claro que falta algo para que tal flauta seja uma flauta: falta-lhe o exercício de sua função, a qual só pode ser desempenhada com a intervenção de um flautista. Como o flautista é um fator externo à flauta, pode-se dizer que a flauta não é tal que "nada lhe falta para ser uma flauta", pois, sem o flautista, lhe falta o desempenho de sua função 
própria, e somente por tal desempenho ela se torna plenamente aquilo que ela é. Esse arrazoado mostra a necessidade de explicar melhor como entendemos a noção de "todo acabado e perfeito". Pretendo elucidar tal noção, primeiramente, através da formulação de critérios conceitualmente claros para aplicá-las, no contexto que nos interessa; em seguida, pretendo elucidá-la através do contraste com aquilo que, para Aristóteles, não satisfaz tais critérios (isto é, os entes contidos nas demais categorias).

Assim, julgo que Aristóteles concebe uma noção de "prioridade em substância", definida pela conjunção dos seguintes critérios: " $A$ é anterior em substância a $B$ ” se e somente se:

(i $i_{7} A$ constitui um todo perfeito e acabado, no qual $B$ pode estar de certo modo incluído;

(ii 7 ) $B$ não constitui um todo acabado, no qual se pudesse dizer que $A$ está incluído.

Tais critérios estão longe de serem claros e exigem elucidação. Meu ponto consiste em dizer que "choriston", longe de introduzir a noção de algo "capaz de ser separado de $B$ " no sentido de "poder existir sem a existência de $B$ ", introduz noção bem mais complexa. Ouso dizer que a assimetria envolvida na afirmação de que " $A$ é choriston em relação a $B$ " não pode ser caracterizada em termos de dependência e independência. Considere-se que $A$ depende de $B$ para ser o que é essencialmente, assim como $B$ depende de $A$ para ser o que é essencialmente. Ora, é compatível com essa dependência mútua certa assimetria pela qual se possa dizer que $A$ é uma entidade que, ainda que dependa de $B$ para ser o que é, é "capaz de tornar $B$ um elemento de si mesmo, num todo articulado", ao passo que $B$ é uma entidade que jamais poderia fazer de $A$ (que é um item do qual depende para ser o que é) um elemento contido em $B^{41}$. Assim, dizer que $B$ não é separado de $A$ consiste em dizer que $B$ não constitui, no sentido relevante, um todo acabado, o qual pudesse, por sua natureza, tornar $A$ um elemento de si mesmo, num todo articulado. Meu argumento pressupõe que a possibilidade de uma situação em que, sendo $A$ anterior em substância a $B$, nem $A$ nem $B$ podem existir separadamente um do outro. Seja $A$ uma substância, seja $B$ uma qualidade. Por um lado, não há nenhuma qualidade que possa existir sem que exista uma substância na qual ela esteja inerente. ${ }^{42}$ Por outro, não há nenhuma substância que possa existir sem que exista uma qualidade que lhe seja atribuída. 
Não há nenhuma assimetria quanto às condições de existência de ambos os itens, pois ambos dependem um do outro para existir. Além disso, pode-se até mesmo conceder que $A$ e $B$ são mutuamente dependentes no sentido de que $A$ não pode ser o que $A$ é sem $B$ ser o que $B$ é, e viceversa. ${ }^{43}$ No entanto, mesmo nessas condições, há clara assimetria no que diz respeito à perfectibilidade, no sentido de que uma substância apresenta-se como um todo acabado do qual a qualidade constitui um elemento, ao passo que a qualidade jamais pode ser entendida como um todo acabado do qual a substância fosse um elemento.

Tomemos um exemplo: seja "corpo" a substância em questão, seja "dotado de volume" a qualidade em questão. Não pode existir corpo algum que não seja dotado de volume e, simetricamente, não pode existir coisa alguma que, sendo dotada de volume, não seja um corpo. No entanto, é o corpo que se apresenta como algo acabado, do qual é elemento a propriedade de ser dotado de volume, ao passo que não seria correto dizer que a propriedade de ser dotado de volume é um todo acabado, da qual o corpo seria um elemento. É por essa razão que a substância "corpo" é um subjacente (hypokeimenon) e a propriedade "ser dotado de volume" não é um subjacente. Pode-se admitir de imediato a predicação "corpo é dotado de volume", ou "o corpo é dotado de volume", mas as predicações "dotado de volume é corpo" ou "o dotado de volume é corpo" não soam como naturais: na penúltima, diríamos que a ordem natural dos termos foi invertida, ao passo que, na última, o artigo introduzido antes da expressão "dotado de volume" parece já carregar consigo a pressuposição de que tal expressão "refere-se a algo subjacente", algo que seria distinto da propriedade de ser dotado de volume. ${ }^{44}$ Assim, não é por acaso que Aristóteles menciona, em Metafísica V 11, a prioridade do subjacente como razão que preponderantemente explica por que a substância é anterior a todos os demais entes (1019a 5-6).

A noção de "prioridade em substância" que aparece em Metafísica IX 8 pode, no meu entender, ser tomada do mesmo modo. Quero dizer que se trata da mesma noção que, em 1077b 2-3, é introduzida pelo critério da excedência pelo ser. Aristóteles diz que a efetividade (energeia) é "anterior em substância" à capacidade (dunamis) pelas mesmas razões, ou, talvez, por razões estritamente análogas: $\left(i_{7}\right)$ a efetividade constitui algo a que 
nada falta, no qual a potência pode estar de certo modo incluída; (ii $)$ mas a potência não constitui um todo acabado, algo a que nada falta, no qual se pudesse dizer que a efetividade está incluída. Ora, falta à potência, de fato, o exercício efetivo da atividade da qual ela é potência. Por razões similares, pode-se dizer que o adulto é "anterior em substância à criança" (1050a 5-6), porque $\left(i_{7}\right)$ o adulto constitui um todo perfeito e acabado, algo a que nada falta, em referência ao qual a criança pode ser entendida como uma etapa em sua gênese e desenvolvimento; (ii 7 ) mas a criança não constitui um todo acabado, em referência ao qual o adulto pudesse ser entendido como uma etapa em sua gênese e desenvolvimento. ${ }^{45}$

Talvez, no entanto, fosse preferível dizer que a noção de "prioridade em substância" devesse ser entendida por alguma composição entre os critérios $\left(i_{5}\right)-\left(i_{5}\right)$ e $\left(i_{7}\right)-\left(i i_{7}\right)$, ou seja, por alguma combinação entre os requisitos que dizem respeito à existência independente e os requisitos que dizem respeito à noção de todo acabado. De fato, os requisitos relativos à separabilidade em existência parecem desempenhar um papel relevante na tese de que, entre as substâncias, as eternas e as incorruptíveis têm primazia sobre as corruptíveis. Voltarei a esse ponto no final deste artigo.

V.

Em vez de imediatamente explorar diversos pontos que poderiam ser discutidos a respeito dessa noção de "prioridade em substância" ou "prioridade em excedência do ser", assinalada pelo termo "choriston", passo a outro problema, que consiste no seguinte: tudo aquilo que Aristóteles designa como "ousia" satisfaz plenamente, sem restrições, essa noção de prioridade em substância? A resposta a que tenderíamos naturalmente parece ser positiva, afinal, a prioridade em substância parece derivar seu próprio nome das coisas a que apropriadamente se aplica. No entanto, a resposta é negativa em Metafísica 1042a 28-29. A forma é reconhecida sob o título de "ousia", mas não é separada sem restrições (haplôs). Conseqüentemente, a forma, embora seja uma ousia, não satisfaz o tipo de prioridade que se atribui às substâncias: de fato, a forma não tem completude (tampouco tem existência independente). Para entender 


\section{4}

melhor quais são as razões de Aristóteles para essa restrição, é conveniente introduzir, finalmente, o sétimo tipo relevante de prioridade, a prioridade causal-explanatória. Esse tipo de prioridade pode ser definido do seguinte modo. Deve-se dizer que $A$ é anterior a $B$ se e somente se forem conjuntamente satisfeitos os seguintes requisitos:

(i8) $A$ explica adequadamente por que $B$ é o caso;

(ii8) mas $B$ não explica adequadamente por que $A$ é o caso ${ }^{46}$.

Esse tipo de prioridade tem relações estreitas com a prioridade na ordem do conhecimento por natureza e com a prioridade definicional. No entanto, ela tem sua especificidade. Por um lado, esse tipo de prioridade não depende de nenhuma referência ao cognoscente e, nesse sentido, talvez seja inconveniente rotulá-la com o adjetivo "explanatória" e defini-la em termos de "explicação". Trata-se de um tipo de prioridade que Aristóteles julga estar inscrito na ordem das coisas, e a prioridade pelo conhecimento nada mais faz do que refletir essa ordem das coisas. Nesse sentido, a noção de explicação adequada nada mais é senão a contraparte de uma relação causal ${ }^{47}$ que pertence ao domínio das coisas. Conseqüentemente, a prioridade causal-explanatória poderia ser, talvez, mais bem captada pela seguinte definição:

$\left(\mathrm{i}_{8}{ }^{\prime}\right) A$ faz $B$ ser aquilo que $B$ é;

(ii $\left.{ }_{8}{ }^{\prime}\right)$ mas $B$ não faz $A$ ser aquilo que $A$ é. ${ }^{48}$

Por outro lado, talvez seja correto dizer que a prioridade definicional está incluída na prioridade causal como um de seus tipos, mas a prioridade causal é mais ampla e pode envolver eventos entre os quais não vigora nenhuma relação definicional. ${ }^{49}$ É também importante ressaltar que a prioridade causal de modo algum poderia ser reduzida à prioridade lógica. Aristóteles distingue claramente casos em que, do ponto de vista lógico, há total simetria entre dois termos que se relacionam como causa e efeito, pois ambos se implicam mutuamente e/ou são estritamente coextensivos. Não obstante, apesar da simetria do ponto de vista da "implicação do ser o caso", há assimetria decisiva, pela qual um se apresenta como causa e o outro, como efeito. Aristóteles reconhece isso explicitamente ao apresentar a noção de prioridade causal, em Categorias 14b 1022: o fato de $x$ ser homem e a verdade da predicação " $x$ é homem" se implicam mutuamente, mas é o fato que é causa da verdade da predicação, não o inverso. Aristóteles reconhece o mesmo ponto de modo 
explícito em dois outros contextos relevantes, que lidam com a noção de causa envolvida nas explicações científicas: em Segundos Analíticos 78a 2438 (o fato de os planetas não cintilarem e o fato de os planetas estarem perto da Terra se implicam mutuamente, mas é o segundo que é causa do primeiro, não o inverso) bem como em Segundos Analíticos 98b 4 ss. (o fato de a Terra estar interposta entre o Sol e a Lua e o fato de a Lua sofrer eclipse se implicam mutuamente, mas é o primeiro que é causa do segundo, não o inverso) $)^{50}$.

Tomemos como exemplo os termos "ser humano" e "dotado da função de pensar discursivamente". ${ }^{51}$ Entre eles, não há assimetria na implicação do ser o caso, pois a verdade de " $x$ é ser humano" sempre é acompanhada da verdade de " $x$ é dotado da função de pensar" e viceversa, de modo que não vigora nenhuma relação de prioridade lógica entre esses termos. De fato, eles são termos co-extensivos. De modo similar, não há entre esses termos nenhuma assimetria quanto às condições de existência, pois nenhum deles pode "existir" sem o outro. Isso quer dizer que é impossível existir um ser humano sem que exista a função de pensar discursivamente, bem como é impossível que a função de pensar discursivamente exista (isto é, seja instanciada em um dado indivíduo) sem a existência de um ser humano. No entanto, há assimetria quanto à prioridade definicional e quanto à prioridade causal-explanatória (as quais, neste caso, se coadunam): de fato, $\left(i_{8}\right)$ a função de pensar explica adequadamente por que o ser humano é o que é; (ii ${ }_{8}$ ) mas a noção de ser humano não explica adequadamente por que a função de pensar é como é. De modo similar, $\left(i_{2}\right)$ a função de pensar pode ser definida independentemente da noção de ser humano, por um enunciado definiens em que o termo "ser humano" não é mencionado nem está implicitamente contido; (ii ${ }_{2}$ ) mas o ser humano não pode ser definido independentemente da função de pensar, ao contrário, o enunciado definitório de "ser humano" inclui a função de pensar como um de seus termos. De tudo isso resulta que a função de pensar discursivamente é anterior ao ser humano não apenas segundo a prioridade definicional, mas também segundo a prioridade causal-explanatória.

De fato, pode-se dizer que a função de pensar é a forma e a ousia (essência) do ser humano. ${ }^{52}$ No entanto, devemos indagar se, sendo a ousia do ser humano, a função de pensar satisfaz os requisitos da priori- 
dade "em substância", pela qual ela poderia ser designada como algo "sepadado" e, enfim, como uma "substância", em absoluto (quero dizer, não como "substância de algo", mas como "substância" pura e simplesmente). A resposta de Aristóteles é negativa. A forma de uma entidade sensível não é "separada sem mais", mas apenas "separada logôi" (cf. Metafísica 1042a 28-31). ${ }^{53}$ A função de pensar não pode ser concebida como um todo acabado do qual o ser humano pudesse tornar-se um elemento. É antes o inverso: é o ser humano que é um todo acabado, do qual é elemento a função de pensar. Por essa mesma razão, a função de pensar discusivamente não satisfaz os requisitos da prioridade em existência: se não existisse ser humano, não existiria a função de pensar discursivamente. Mas sua incapacidade de existir sem o ser humano não é a razão principal pela qual o título de "substância" e "algo separado sem mais" lhe são negados.

Assim, embora seja a ousia do ser humano, nem por isso a função de pensar satisfaz os requisitos da prioridade "em substância”, pela qual ela poderia ser designada como algo "separado" e, enfim, como uma "substância", em absoluto (não apenas omo "substância do ser humano").

VI.

É bem importante para meus propósitos, nesse momento, ressaltar que a prioridade causal, que é absolutamente relevante para caracterizar a noção de "ousia" no livro VII da Metafísica, não se deixa reduzir à prioridade em existência, tampouco é sempre acompanhada pela prioridade em existência. ${ }^{54}$ Por que é importante ressaltar esse ponto? Porque certos adversários de Aristóteles conceberam que a prioridade causal dependeria da prioridade em existência separada, ou mesmo seria redutível a ela. Traços dessa concepção adversária afloram claramente na exposição de um dos lados da nona aporia no livro III da Metafísica. O texto é o seguinte: "um princípio e uma causa devem ser à parte das coisas de que são princípio e causa, isto é, devem ser capazes de existir separadamente delas; mas por que alguém conceberia que algo é de tal modo separado do particular, a não ser porque se predica universalmente, isto é, de todos?” (999a 17-21).

Em outro momento, argumentei detalhadamente sobre os problemas 
de interpretação dessa passagem ${ }^{55}$. Agora, no entanto, meu objetivo é bem simples. Quero apenas ressaltar que, para certos adversários de Aristóteles, a prioridade causal (aquela pela qual uma causa se delimita enquanto causa) depende do requisito de ser separada daquilo de que é causa. Ainda que essa separabilidade possa ser entendida, de modo amplo, como algo indeciso entre a prioridade lógica e a prioridade em existência, comparação com os textos relevantes mostra que os adversários de Aristóteles conceberam que a prioridade causal, que caracteriza uma causa enquanto causa, dependeria da prioridade em termos de existência: poderiam ser causas de $X$ apenas coisas que puderem existir separadamente de $X$. Mais do que isso. Talvez esses adversários tenham concebido que a prioridade causal deveria ser inteiramente reduzida à prioridade em existância: poderiam ser causas de $X$ apenas as coisas que fossem assimetricamente independentes de $X$ em existência.

Quem são os adversários que propuseram essa tese? São os mesmos adversários que usaram, como noção preponderante de prioridade, a prioridade como independência quanto às condições de existência (a qual se faz acompanhar, na concepção deles, pela prioridade lógica). Aristóteles relata essa opinião em Metafísica V 11: "são anteriores em natureza e em substância as coisas que podem ser sem outras, sem que essas outras possam ser sem elas - concepção da qual se utilizou Platão" (1019a 2-4).

Admito que a formulação desse tipo de prioridade "em natureza e em substância" é vago e poderia ser entendido ou em termos de prioridade lótgica, ou em termos de prioridade em existência, ou mesmo em termos não muito alheios à prioridade definicional. ${ }^{56}$ No entanto, creio que Aristóteles está a mencionar, nesse contexto, exatamente a concepção platônica segundo a qual seriam anteriores em substância as coisas que satisfazem o requisito da existência separada. De acordo com essa concepção, as coisas anteriores em substância são exatamente as que merecem o título de "substâncias". Mas o requisito da existência separada valeria também (ou sobretudo) para as causas e princípios, como fica claro em Metafísica 999a 17-21. De fato, essa concepção platônica não apenas concebe a prioridade em substância em termos de existência independente, mas também reduz a prioridade causal à prioridade em existência. Por essa concepção, as mesmas coisas que, por um lado, mais 


\section{8}

satisfazem os requisitos da prioridade em existência e contam como substâncias (que são os entes primeiros) também satisfazem, por outro lado, os requisitos da prioridade causal e contam como primeiras causas $e$ primeiros princípios.

Quais coisas foram favorecidas por essa concepção adversária? Quero dizer: quais são os itens que os adversários platônicos de Aristóteles identificaram, por tais requisitos, como sendo os primeiros princípios e como sendo as substâncias? A resposta é clara: "os universais e os gêneros" (1028b 34-35, 1042a 15-16), bem como as Formas (1028b 18 ss., 1042a 15), pois "é pelo mesmo argumento que todos esses itens parecem ser ousiai" $(1042 \mathrm{a} 16)^{57}$.

É contra esses adversários que Aristóteles escreve os livros VII-VIII da Metafísica. Aristóteles quer discutir esse "mesmo argumento" do qual depende a presumida primazia causal e ontológica das Formas platônicas. Em outras palavras, Aristóteles quer discutir e refutar as razões (os porquês, 1028b 30) que os platônicos teriam alegado para introduzir as Formas como, por um lado, substâncias separadas das entidades sensíveis e, por outro, como primeiras causas e primeiros princípios. Aristóteles quer mostrar (a) que as duas ordens de indagação não podem ser resolvidas pelos mesmos critérios e (b) que os Platônicos propuseram respostas incorretas para ambas. Quanto a este segundo ponto, Aristóteles argumenta que, para discernir o que conta como substância, deve-se observar o requisito da prioridade "em excedência pelo ser" (Metafísica 1077b 3), ao passo que, para discernir o que conta como causa das coisas sensíveis, deve-se observar o requisito da prioridade causal-explanatória. $\mathrm{E}$ - atendendo ao primeiro ponto - Aristóteles mostra que os resultados desses requisitos não se acompanham entre si, ou ao menos não se acompanham entre si do modo pelo qual os platônicos pretenderam, ao introduzir a teoria das Formas.

Os livros VII e VIII da Metafísica ocupam-se apenas com essa tarefa negativa de discussão e refutação das pretensões platônicas, embora, ao realizar essa tarefa, eles tenham dito muitas coisas que esclarecem de que modo se deve conceber a prioridade causal-explanatória que é característica da ousia. De modo similar, na medida em que a prioridade causal-explanatória da ousia tem fortes conexões com a prioridade no conhecimento por natureza e com a prioridade definicional, os livros VII e VIII da Metafísica dizem muitas coisas a respeito do modo pelo qual as 
entidades sensíveis devem ser definidas e a respeito das condições pelas quais se pode alcançar conhecimento científico a respeito delas. No entanto, a tarefa principal desses livros é refutativa. Julga-se que a noção aristotélica de ousia obedeceria aos requisitos da prioridade em existência e aos requisitos da prioridade causal. Os livrosVII eVIII da Metafísica vêm mostrar que a relação entre a noção de ousia e as noções de prioridade é bem mais complexa. Primeiro, é incorreto explicar a primazia ontológica da substância por sua presumida anterioridade em existência - pois é simplesmente falso, como vimos, dizer que uma substância pode existir independentemente de propriedades das demais categorias. Longe de satisfazer os requisitos para a prioridade em existência, a substância satisfaz os requisitos da prioridade em termos de "excedência no ser", pela qual se delimitam as noções de "todo acabado" e "separado". Além do mais, ao menos no mundo sublunar, a prioridade ontológica que é característica própria da substância não é acompanhada pela prioridade causalexplanatória. Os itens que satisfazem a prioridade causal-explanatória são substâncias conforme outro uso da expressão: são substâncias de algo (ou, como prefiro, são essências de algo), mas não são substâncias que satisfizessem sem restrições o requisito relevante pelo qual se caracteriza a primazia ontológica das substâncias. ${ }^{58}$

Ao mesmo tempo, ao cumprir sua tarefa refutativa, os livros VII eVIII da Metafísica abrem caminho para a concepção de uma substância suprema, o Primeiro Motor, na qual a prioridade "em excedência pelo ser" (ou em perfeição) é acompanhada pela prioridade "em existência", bem como, de certo modo, pela prioridade causal-explanatória (dado que o Primeiro Motor é, em certo sentido, causa de todas as coisas). Mas isso já é assunto para outro artigo.

${ }^{1}$ Ver o uso da expressão "anteriores pelo ser" em Metafísica 1077b 13.

${ }^{2}$ Em Metafísica 1050a 4 ss., a noção de prioridade em substância aplica-se ao par potencialidade/ efetividade, de modo que se dirá que a efetividade é anterior em substância à potencialidade. Pode-se dizer que a efetividade é uma substância no mesmo sentido em que animais são substâncias?

${ }^{3}$ Meu objetivo é modesto, porém. Não pretendo apresentar estudo exaustivo dos tipos de prioridade reconhecidos por Aristóteles, mas apenas mapeá-los de modo suficiente para elucidar o tipo de prioridade que compete à substância. Para estudos mais exaustivos sobre o 
assunto, ver Cleary 1988, Peramatzis 2008.

4 Observa que não há exata sobreposição entre esses três tipos e os três tipos reconhecidos em Metafisica 1028a 30-32. Para a prioridade lógica, ver Categorias 14a 29-35; para a prioridade definicional, ver Metafisica 1028a 34-7; 1018b 34-7, 1077b 3-4; para a prioridade em conhecimento, ver Segundos Analíticos 71b 33 - 72a 5.

5 É preciso atenção com terminologia: se $A$ "acompanha" $B$, isso quer dizer que $B$ "se segue" de $A$. De fato, " $A$ acompanhar $B$ " quer dizer que " $A$ não pode ser dado separadamente de $B$ ", ou seja, $B$ é condição necessária para $A$ ser o caso, de modo que "todo $A$ é $B$ ". Na verdade, talvez fosse mais correto traduzir "akolouthein" por "se faz acompanhar por", ou simplesmente por "implica".

${ }^{6}$ Ao menos conceda-se isso em vista do argumento! Não há evidências de que Aristóteles tenha considerado a possibilidade de existir um animal imortal - a não ser que pensemos no Primeiro Motor Imóvel. Mas, no mundo sublunar ao menos, todos os animais são mortais, e isso basta para meu ponto.

7 Esclareço ao leitor que minha terminologia é bem diferente daquilo que se pode encontrar em certa literatura, na qual a expressão "prioridade lógica" é vaga e confusamente usada para designar aquilo que, adiante, caracterizarei como prioridade definicional. Aristóteles designa a prioridade definicional pelo termo no dativo "logoi" (Metafísica 1028a 32, 34) ou pela expressão "kata ton logon" (Metafísica 1018b 34). Mas traduzir essas ocorrências de "logos" pelo adjetivo "lógica" revela estreita concepção do que vem a ser lógica e do que vem a ser uma definição!

8 Poder-se-ia alegar que Segundos Analíticos 72a 29-32, Metafísica 993 b 27 dá suporte a essa leitura.

${ }^{9}$ Se poderia apontar para Metafísica 1018 b 34-7, texto que, no entanto, é um caso controverso entre prioridade lógica e definitória (no meu entender, introduz a prioridade definitória, não a lógica).

10 Neste caso, o "ser" da expressão "poder ser sem" (ou equivalente), em Metafísica 1019a 24, por exemplo, não quer dizer nada mais senão "ser instanciado em um dado indivíduo". Ou seja, nesse contexto, "ser", para o termo homem, quer dizer "ser verdadeiramente atribuído a um dado indivíduo”. Para outra intepretação, ver Peramatzis 2008: p. 189, 196-200. No entanto, não pretendo que esse seja o sentido padrão de "ser" em todos os casos em que se fala do "ser" de um dado termo. Há contextos em que "ser", para o termo homem, quer dizer "ser aquilo que ele é”.Ver Peramatzis 2008: p. 198-9. Minha discordância em relação a Peramatzis resume-se aos contextos em que se deve apropriadamente aplicar uma ou outra compreensão da noção de "ser".

11 Makin 2003: p. 210 ss. (ver também Makin 2006: p. 192-3), julga unilateralmente que "ser", em todos os contextos em que se fala em prioridade envolvendo o "ser", deveria ser entendido como "existência". Contra Makin, tem inteira razão Peramatzis 2008: p. 200-7, 216-20, 233-5, que discute exaustivamente a inviabilidade de se tomar a prioridade da substância em termos de existência independente.

12 Um dos desastres mais devastadores na interpretação de Aristóteles consiste em não distinguir esses dois tipos de prioridade. Transforma-se assim o essencialismo aristotélico em algo

doispontos, Curitiba, São Carlos, vol. 7, n. 3 - especial, p.75-106, abril, 2010 
que conceberia a noção de essência como um aglomerado de condições necessárias para conceber algo, as quais, uma vez aglomeradas, tornam-se também suficientes para identificar aquilo de que seriam a essência.Ver Cohen 1978: 83.

13 Cf. Meteorologica 390a 10-20.

${ }^{14}$ Ver a nosso favor o argumento pioneiro de Kung 1977: 362-3.

15 Não discutirei neste artigo os tipos de prioridade "conforme à capacidade e a efetividade" (a "conforme a potência e ato", nos termos tradicionais), mencionados de modo bem obscuro em Metafisica 1019a 6-14, e objeto de discussão entre Makin 2003 e Peramatzis 2008. Discutir esse tipo de prioridade tornaria este artigo excessivamente longo.

16 O exemplo vem de Sheldon Cohen, 1996: p. 37-45.

$17 \mathrm{O}$ mesmo resultado pode ser obtido ainda que se rejeite a proposta de Cohen para definir os elementos. Suponha, assim, que a terra fosse definida pelo seguinte enunciado: "terra é (df.) o elemento que se move naturalmente para o centro do universo" (que é a definição sugerida, a meu ver erradamente, por Gill 1989: p. 239). Se a prioridade lógica acompanhasse todos os casos de prioridade definicional, seria preciso que a verdade de " $x$ se move naturalmente para o centro do universo" sempre se seguisse da verdade de " $x$ é terra". No entanto, essa conseqüência não se verifica na maior parte dos casos: boa quantidade do elemento terra está em repouso. Se a referida conseqüência se verificasse sempre, os torrões de terra submetidos ao movimento contra-natural, quando alguém os atirasse para cima, deixariam de ser terra e logo depois se transformariam em terra novamente, ao passarem a se mover para o centro, o que é bem implausível.

18 Essa distinção é bem clara em Segundos Analíticos 71b 33- 72a 5. Examinei esse passo com algum detalhe em Angioni 2001, p. 308-313.

19 Cf. Segundos Analíticos I 18: o conhecimento obtido pela sensação é condição necessária para os conhecimentos universais. Ver também Física 188b 31-33, 189a 4-8.

${ }^{20}$ A não ser que não saibamos que este cavalo existe, ou a não ser que não saibamos que isto que estamos a perceber é um cavalo. Aristóteles discute situações desse tipo em Segundos Analíticos 71a 24- b8 (texto discutido por Bronstein neste volume) e Primeiros Analíticos 67a 27- b 11. Mas elas não afetam meu argumento. Não pretendo dizer que, se sabemos que todo cavalo é herbívoro, conhecemos todos os cavalos que existem (o que seria absurdo). Meu ponto é que saber que todo cavalo é herbívoro consiste em saber que, para todo x, se x é um cavalo, x é herbívoro.

21 Em Segundos Analíticos 89b 37 ss., "X ser o caso" é introduzido como algo de que há uma causa e um mediador, de modo que se torna claro que " $X$ ser o caso" equivale ao fato predicativo em que uma propriedade $A$ se atribui a um sujeito $C$, resultando naquilo que $X$ é, a saber, $C-A$. "X ser o caso" equivale a " $X$ ser $C-A$ " ou " $X$ ser sua essência" (cf. 90a 9-10). Essa interpretação não é, porém, pacífica, sobretudo no que concerne à passagem 90a 9-10: ver discussão em Charles 2000: 275, n3; Barnes 1993: 205 (que omite "ousian" do texto e surpreendentemente não se justifica em seu comentário).

${ }^{22}$ Ver Peramatzis 2008: p. 189-91, 196-200 e sua noção de "priority in being".

doispontos, Curitiba, São Carlos, vol. 7, n. 3 - especial, p.75-106, abril, 2010 
23 Ao dizer que um tipo de prioridade "corresponde" a outro, quero dizer que eles geram, extensionalmente, os mesmos resultados.

${ }^{24}$ A conjunção desses requisitos, apresentada por Aristóteles em Metafísica 1019a 2-4, tem sido discutida sob o título de "independence condition" (IC) na literatura secundária. Ver Makin 2003: p. 210-2, e Peramatzis 2008: p. 187, 192. Concordo com os resultados filosóficos da discussão de Peramatzis contra Makin, resultados que ficam bem próximos às noções de prioridade causal-explanatória e prioridade em substância que introduzirei logo mais. No entanto, do ponto de vista exegético, discordo de Peramatzis 2008: p. 192-200, quanto aos propósitos de Aristóteles em Metafísica 1019a 2-4. Não julgo que Aristóteles queira defender, em 1019a 2-4 ss., seu tipo preferido de prioridade, julgo que Aristóteles apenas inclui na lista um tipo de prioridade introduzido pelos platônicos, o qual parece poder ser entendido em termos de prioridade lógica e/ou prioridade em existência.

25 A tradutibilidade recíproca entre as sentenças " $x$ é animal” e "animal existe" não é um ponto incontroverso. Para análises detalhadas, ver Kahn 1997: p. 110, 113 e Matthen 2003: p. 126.

${ }^{26}$ Ver Física 194b 13, Metafisica 1071a 15-6, Geração e Corrupção 336a 31-2 ss.

27 Suponha-se, em vista do argumento, que dragões são quadrúpedes...

28 Dito de outro modo, a prioridade lógica é aplicável às relações entre classes vazias.

29 Cf. Metafisica 1028a 30-32.

30 Aristóteles parece admitir esse segundo ponto em Metafísica 1028a 35-36, 1045b 29-31.

$31 \mathrm{Tal}$ interpretação remonta a Alexandre de Afrodísia.Ver Ross 1924: p. 160-1.

32 Tratei desse assunto com detalhe nos meus comentários a Física I 7, em Angioni, 2009: p. $148-58$.

33 Ambas essas questões, mas sobretudo a última, foram tratadas com esmero por Peramatzis 2008 e Corkum 2008. Embora não concorde com Peramatzis em várias questões exegéticas, considero que nossas interpretações inspiram-se nas mesmas motivações filosóficas básicas.

${ }^{34}$ Ver argumentos similares em Corkum 2008: p. 72-3, e Peramatzis 2008: p. 202-3.

35 Exceções são os recentes artigos de Peramatzis 2008 e Corkum 2008.

36 Mas até mesmo a satisfação desse requisito é problemática e envolve confusão entre types e tokens.Ver discussão excelente e pormenorizada em Corkum 2008: p. 72-3, 77-8.

37 Não discutirei em pormenor essa tese. Julgo que ela está muito bem estabelecida em Peramatzis 2008: p. 202-4 e Corkum 2008: p. 72-4. Nenhuma substância pode existir independentemente de suas propriedades, as quais se classificam sob outras categorias do ser. A prioridade ontológica da substância sobre as demais categorias não pode, portanto, ser entendida como prioridade em existência.

38 Argumentei em favor dessa co-extensão em Angioni 2008: p. 137-42

39 Discordamos de Fine 1984: p. 35-8, que pretende que o vocabulário da "separação" tenha sido introduzido exatamente para exprimir a prioridade em existência.

doispontos, Curitiba, São Carlos, vol. 7, n. 3 - especial, p.75-106, abril, 2010 
40 Argumentei com algum detalhe em favor desse leitura em Angioni, 2008, pp. 74-75.

41 Usei o termo "elemento", não o termo "parte", para evitar inconsistência com a definição que Aristóteles dá em Categorias 1a 24-25 para a relação "estar em algo subjacente”, a qual implica que uma propriedade de outra categoria, embora esteja na substância como em algo subjacente, não é uma parte dessa substância. O texto é o seguinte: "digo que 'está em algo subjacente' aquilo que está presente em algo, não como parte, e que não pode ser separadamente daquilo em que está" (1a 24-25).

42 Cf. Corkum 2008: p. 78-9.

43 Considere-se, por exemplo, a relação entre uma substância individual e uma propriedade que lhe é peculiar: Sócrates e a sabedoria-de-Sócrates. Uso hífens para deixar claro que me refiro a uma "entidade não-substantial singular e não-recorrente", ou seja, a um "indivíduo não-substancial” (no sentido Strawsoniano, cf. Individuals p. 146), ainda que a atribuição de tal noção a Aristóteles seja controversa (cf. Corkum 2008: p. 78-80). Podemos admitir que nem Sócrates continuaria a existir sem sua sabedoria-de-Sócrates (pois já não seria o Sócrates que conhecemos por esse nome), nem a sabedoria-de-Sócrates poderia existir sem a existência de Sócrates. Podemos também admitir que Sócrates contribui de modo relevante para determinar o que é a sabedoria-de-Sócrates, assim como a sabedoria-de-Sócrates contribui de modo relevante para determinar o que (ou quem) Sócrates é.

44 Desenvolvi com detalhe as diferenças semânticas entre esses dois tipos de predicação em Angioni 2007b.

45 Para interpretação bem diversa, ver Makin 2003: p. 225-30 e Witt 1994: p. 217-8, 224. Para crítica contundente dessas interpretações, ver Peramatzis 2008: p. 230-4.

46 Sobre a expressão "ser o caso", ver nota 21, sobre Segundos Analíticos $89 \mathrm{~b} 37$ ss.

47 Uso a expressão "relação causal" para me referir à concepção aristotélica de aition, que pode ser brevemente resumida do seguinte modo: certa propriedade F é tal que sua presença em um dado sujeito é fundamento para a presença de outra propriedade $G$ no mesmo sujeito. Obviamente, não estou a usar a noção de "causa" tal como entendida em contextos humeanos.

48 Essa noção de prioridade é bem próxima daquilo que Peramatzis 2008: p. 189, chamou de "priority in being [what something is]". Às vezes, Peramatzis chega a esclarecer sua noção nos termos causais que aqui propomos (especialmente nas pp. 238-9, 241), mas por vezes não fica inteiramente claro como ele entende a relação entre assimetria causal e dependência ("não poder ser [o que algo é] sem o outro termo").Ver a esse respeito sua formulação na p. 206.

49 Por exemplo: é o fato de os planetas estarem perto da Terra que explica por que os planetas não cintilam (cf. Segundos Analíticos 78a 37-38), mas parece não haver nenhuma conexão definicional entre ambos esses fatos; de modo similar, a interposição da Terra entre o Sol e a Lua tem prioridade causal sobre a privação de luz na Lua, mas parece não haver conexão definicional entre ambos os fatos (98b 16-19), embora isso seja controverso. Nesse ponto, nossa interpretação é diferente da noção de "priority in being" de Peramatzis 2008: p. 189-90, que a entende como mera contrapartida ontológica da prioridade definicional.

doispontos, Curitiba, São Carlos, vol. 7, n. 3 - especial, p.75-106, abril, 2010 
50 Nesse texto, Aristóteles fornece também outro exemplo, envolvendo dois fatos que se implicam mutuamente, entre os quais não há, porém, nenhuma relação causal: o fato de as videiras terem folhas largas e o fato de as videiras perderem as folhas no outono. $\mathrm{Na}$ verdade, essas três passagens são apenas aquelas em que Aristóteles é bem explícito a respeito da distinção entre prioridade lógica e prioridade causal-explanatória. Na verdade, sua teoria da demonstração científica funda-se na tese básica de que uma explicação pela causa adequada exige, como condição necessária (embora, obviamente, não suficiente) a implicação mútua entre explanandum e explanans. Defendi essa interpretação em Angioni, 2007.

51 O advérbio "discursivamente" é necessário para marcar que se trata do pensamento que é próprio de seres humanos, não de seres divinos (embora seja controverso saber se Aristóteles tem uma doutrina consistente sobre o pensamento de seres divinos).

52 Cf. Ethica Nicomachea 1098a 7-8. Aristóteles não diz explicitamente que a atividade do pensamento é a ousia do ser humano, mas diz explicitamente que é a função (ergon), e em outros textos diz claramente que tudo define-se pela sua função (cf. Meteorologica 390a 510, Metafisica 1035b 16-8) e a definição, obviamente, é o logos da ousia. Alternativamente, poder-se-ia dizer que a ousia do ser humano é sua alma ou, mais precisamente, a parte da alma encarregada de pensar discursivamente. Mas esses detalhes não afetam o meu ponto.

53 Cf. Física 193b 4-5. Talvez essa mesma restrição seja o motivo pelo qual Aristóteles designa a forma pela expressão "ousia kata ton logon" (cf. Metafísica 1035b 15-6).

54 Nesse ponto, meu projeto tem muito em comum com a noção de "priority in being" introduzida por Peramatzis 2008: p. 189-90. Mas, como ficará claro a seguir, minhas motivações exegéticas são bem diversas das de Peramatzis.

55 Angioni, 2008, pp. 60-83.

56 Peramatzis 2008: 189-191, interpreta a fórmula em termos de "priority in being". Quanto à motivação de Aristóteles em Metafísica 1019a 2-4, minha interpretação é bem diversa da de Peramatzis 2008: p. 192-200. Não vejo problema em conceber a noção de "prioridade em natureza e substância", proposta em 1019a 2-4, em termos de prioridade em existência (como faz Makin 2003: p. 213, e Makin 2006: p. 192). O problema é entender se Aristóteles admite essa noção de prioridade como relevante para a sua teoria da substância, ou se ele apenas a menciona como opinião adversária. Adoto esta segunda opção e julgo a primeira (que é a de Makin) inaceitável.

57 Mais literalmente, o texto diz "pois as Formas parecem ser ousia pelo mesmo argumento que se aplica aos universais e ao gênero", mas isso obviamente equivale a dizer que Formas, universais e gênero se credenciam ao título de ousia pelo mesmo argumento.

58 Peramatzis 2008: p. 189-90, 238-9, concebe sua "prioriry in being" como uma prioridade ontológica, mas às vezes me parece que nossa divergência é meramente verbal quanto a esse ponto. Ao afirmar que as formas, que são essências primeiras conforme à prioridade causalexplanatória, não têm a prioridade ontológica que é típica das substâncias (dos indivíduos concretos), quero dizer apenas o seguinte: as formas não são contadas como itens primeiros na ontologia do mesmo modo pelo qual os indivíduos são assim contados. Isso não me obriga a resvalar para um nominalismo das formas. Admito que a prioridade causal-explanatória das

doispontos, Curitiba, São Carlos, vol. 7, n. 3 - especial, p.75-106, abril, 2010 
formas ou essências tem fundamento ontológico, no sentido em que Peramatzis usa o termo "ontológico".

\section{Referências bibliográficas}

ANGIONI, L. [2001]. "Explanation and Definition in Physics I 1", Apeiron vol. 34, n. 4, p. 307-320.

ANGIONI, L. [2008]. As Noções Aristotélicas de Substância e Essência. Campinas: Editora da Unicamp.

ANGIONI, L. [2009]. Aristóteles - Física I-II. Campinas: Editora da Unicamp.

BARNES, J. [1993]. Aristotle - Posterior Analytics, Oxford: Clarendon Press.

CHARLES, David. [2000]. Aristotle on Meaning and Essence, Oxford: Oxford University Press.

CLEARY, John. [1988]. Aristotle on Many Senses of Priority, Cardondale: Southern Illinois University Press.

COHEN, S. Marc. [1978]. "Individual and essence in Aristotle's Metaphysics”, Paideia (edição especial sobre Aristóteles), p. 75-86.

COHEN, Sheldon M. [1996]. Aristotle on Nature and Incomplete Substance, Cambridge University Press.

CORKUM, Paul. [2008]. "Aristotle on Ontological Dependence", Phronesis 53, p. 65-92.

FINE, Gail. [1994]. "Separation”, Oxford Studies in Ancient Philosophy 2, p. 31-87.

FINE, Kit. [1995]. "Ontological Dependence", Proceedings of the Aristotelian Society 95, p. 269-90.

GILL, Mary Louise. [1989]. Aristotle on Substance: the Paradox of Unity, Princeton University Press 
KAHN, Charles. [1997]. "Alguns usos filosóficos do verbo ser em Platão", in Sobre o verbo grego ser e o conceito de ser, trad. Maura Iglésias et alli. Rio de Janeiro: Núcleo de Estudos de Filosofia Antiga da PUCRJ, p. 107-53.

KUNG, Joan. [1977]. “Aristotle on Essence and Explanation”, Philosophical Studies, vol. 31, n6, pp. 361-383.

MAKIN, Stephen. [2003]. "What Does Aristotle Mean by Priority in Substance", Oxford Studies in Ancient Philosophy 24, p. 209-38

MAKIN, Stephen. [2006]. Aristotle, Metaphysics - Book Theta, Oxford: Oxford University Press (Clarendon Aristotle Series).

MATTHEN, Mohan. [1983]. "Greek ontology and the 'is' of truth", Phronesis 28, p. 113-35.

PERAMATZIS, Michael. [2008]. "Aristotle's notion of priority in nature and substance", Oxford Studies in Ancient Philosophy 36, p. 187 247.

ROSS, D. [1924]. Aristotle's Metaphysics - A revised text with introduction and commentary. 2 vols. Oxford: Clarendon Press.

WITT, Charlotte. [1994]. “The priority of actuality”, in T. Scaltsas, D. Charles and M. L. Gill (edd.), Unity, Identity and Explanation in Aristotle's Metaphysics, Oxford: Oxford University Press. 